\title{
Use of $\operatorname{rec} A$ as an alternative phylogenetic marker in the family Vibrionaceae
}

\author{
C. C. Thompson, ${ }^{1,2}$ F. L. Thompson, ${ }^{1,2}$ K. Vandemeulebroecke, ${ }^{1,2}$ \\ B. Hoste, ${ }^{1,2}$ P. Dawyndt ${ }^{1}$ and J. Swings ${ }^{1,2}$
}

Correspondence

F. L. Thompson

fabiano.thompson@ugent.be

\author{
Laboratory for Microbiology ${ }^{1}$ and BCCM ${ }^{\mathrm{TM}} / \mathrm{LMG}$ Bacteria Collection ${ }^{2}$, Ghent University, \\ K. L. Ledeganckstraat 35, Ghent 9000, Belgium
}

Cultivation-dependent and -independent studies have shown that vibrios are abundant worldwide in aquatic environments, including estuaries, marine coastal waters and sediments, and aquaculture settings (Heidelberg et al., 2002a, b; Suantika et al., 2001; Urakawa et al., 2000). Vibrios are particularly abundant in and/or on marine organisms (Gomez-Gil et al., 1998; Nishiguchi, 2000; Rosenberg \& Ben-Haim, 2002). Several Vibrio species are serious pathogens of aquatic animals (Austin \& Austin, 1999; Lightner \& Redman, 1998). Vibrio anguillarum, Vibrio salmonicida and Vibrio vulnificus are important bacterial pathogens of several fish species, while Vibrio splendidus-related species represent a threat to bivalves, and Vibrio harveyi and Vibrio campbellii to shrimps (Austin \& Austin, 1999; Le Roux et al., 2002). Vibrio cholerae, Vibrio parahaemolyticus and V. vulnificus are pathogens of man (Farmer \& Hickman-Brenner, 1992; Wachsmuth et al., 1994). V. cholerae, the causative agent of cholera, has killed thousands of people worldwide in the last decade (WHO, 2001, 2002; http://www.who.int/en/). In the last 3 years alone, about 10000 people have died of cholera, mainly in developing countries (WHO, 2001, 2002).

According to Bergey's Manual of Systematic Bacteriology (2002) (see http://dx.doi.org/10.1007/bergeysoutline200210),

The GenBank/EMBL/DDBJ accession numbers for the recA sequences reported in this study are AJ580845-AJ580909.

Details of strains used in the study and the $16 \mathrm{~S}$ rDNA/recA regression curve are available as supplementary material in IJSEM Online. there are six genera within the current family Vibrionaceae: Allomonas (one species), Enhydrobacter (one species), Listonella (two species), Photobacterium (six species), Salinivibrio (one species) and Vibrio (44 species). The genera Allomonas (Kalina et al., 1984) and Enhydrobacter (Staley et al., 1987) were tentatively allocated to the family Vibrionaceae based on phenotypic characteristics, but it is now known that Allomonas belongs to Vibrio and Enhydrobacter to Moraxella (Thompson et al., 2003a). Several novel Vibrio species isolated mainly from the aquatic environment and marine organisms have been described in the last few years, including species related to Vibrio tubiashii, i.e. Vibrio brasiliensis, Vibrio coralliilyticus, Vibrio neptunius, and Vibrio xuii (BenHaim et al., 2003; Thompson et al., 2003b); species related to Vibrio splendidus, i.e. Vibrio tasmaniensis, Vibrio kanaloae, Vibrio pomeroyi and Vibrio chagasii (Thompson et al., 2003c, d); species related to Vibrio halioticoli, i.e. 'Vibrio ezurae', 'Vibrio gallicus' and Vibrio superstes (Hayashi et al., 2003; Sawabe et al., 2003); species related to V. harveyi, i.e. Vibrio rotiferianus (Gomez-Gil et al., 2003a) and species related to Vibrio furnissii, i.e. Vibrio pacinii (Gomez-Gil et al., 2003b). The identification of Vibrio species requires the application of genomic analyses, including AFLP, rep-PCR, DNA-DNA hybridization and 16S rDNA gene sequencing (Thompson et al., 2001a).

In order to find new identification markers and improve our knowledge of the phylogenetic structure of vibrios, it is essential to analyse other genes apart from $16 \mathrm{~S}$ rDNA. recA 
has been suggested as a potential marker to unravel phylogenetic relationships among higher taxonomic ranks such as families, classes and phyla because of its ubiquity and house-keeping function in bacteria (Eisen, 1995; Ludwig \& Klenk, 2001; Zeigler, 2003). recA is a multifunctional protein contributing to homologous recombination, DNA repair and the SOS response, and specifically binds stretches of single-stranded DNA, unwinds duplex DNA, and finds regions of homology between chromosomes in homologous recombination (Cox, 2003; Lloyd \& Sharp, 1993). To date, recA gene sequences have been used only to analyse $V$. cholerae strains (Byun et al., 1999; Stine et al., 2000), and their value in discriminating closely related species within the family Vibrionaceae is not known. Our aim in the present study was to analyse the usefulness of recA gene sequences as an alternative phylogenetic and identification marker for vibrios.

The strains used in this study are listed in Supplementary Table A in IJSEM Online. Strains were grown aerobically on marine agar $2216 \mathrm{E}$ (Difco) at $27^{\circ} \mathrm{C}$ for $24 \mathrm{~h}$. All strains included in this study are deposited in the $\mathrm{BCCM}^{\mathrm{TM}} / \mathrm{LMG}$ Bacteria Collection or in the research Collection at Ghent University (Ghent, Belgium). Bacterial genomic DNA was extracted following the methodology described by Pitcher et al. (1989).

PCR mixtures were composed of $33.5 \mu \mathrm{l}$ sterile MilliQ water, $5 \cdot 0 \mu \mathrm{l} 10 \times$ PCR buffer, $5 \cdot 0 \mu \mathrm{ldNTPs}, 0 \cdot 5 \mu \mathrm{l}$ forward primer $\left(10 \mu \mathrm{M} ; 5^{\prime}\right.$-TGGACGAGAATAAACAGAAGGC-3'; Byun et al., 1999), $0.5 \mu \mathrm{l}$ reverse primer $(10 \mu \mathrm{M}$; 5'-CCGTTATAGCTGTACCAAGCGCCC-3'; Stine et al., 2000), $0.5 \mu \mathrm{l}$ AmpliTaq DNA polymerase and $5 \cdot 0 \mu \mathrm{l}$ template DNA $\left(0 \cdot 01 \mu \mathrm{g} \mu \mathrm{l}^{-1}\right)$. PCR was performed using a GeneAmp PCR System 9600 thermocycler (Applied Biosystems). The thermal program consisted of $5 \mathrm{~min}$ at $95^{\circ} \mathrm{C}$, 3 cycles of $45 \mathrm{~s}$ at $95^{\circ} \mathrm{C}, 2 \mathrm{~min}$ at $55^{\circ} \mathrm{C}$ and $1 \mathrm{~min}$ at $72^{\circ} \mathrm{C}$, 30 cycles of $20 \mathrm{~s}$ at $95^{\circ} \mathrm{C}, 1 \mathrm{~min}$ at $55^{\circ} \mathrm{C}$ and $1 \mathrm{~min}$ at $72^{\circ} \mathrm{C}$ and a final extension of $7 \mathrm{~min}$. at $72^{\circ} \mathrm{C}$. Positive PCRs, giving a product with the expected size and intensity, were purified using the Nucleofast 96 PCR clean up membrane system (Macherey-Nagel), which is based on ultrafiltration membranes. Purified PCR products were eluted in sterile MilliQ water. Subsequently, $3 \cdot 0 \mu \mathrm{l}$ purified PCR product was mixed with $1 \cdot 0 \mu \mathrm{l}$ ABI Prism Big Dye Terminator ready reaction mix, $3.0 \mu \mathrm{l}$ forward and/or reverse primer $(4 \mu \mathrm{M})$, $1.5 \mu \mathrm{l} 5 \times$ buffer and $1.5 \mu \mathrm{l}$ MilliQ water. The thermal program consisted of 30 cycles of $15 \mathrm{~s}$ at $96^{\circ} \mathrm{C}, 1 \mathrm{~s}$ at $35^{\circ} \mathrm{C}$ and $4 \mathrm{~min}$ at $60^{\circ} \mathrm{C}$. Sequencing products were purified using the Montage $\mathrm{SEQ}_{96}$ sequencing reaction cleanup kit (Genomics), which removes contaminating salts and unincorporated dye terminators from DNA sequencing reactions. Purified sequencing products were then dried in an Eppendorf Concentrator 5301 at room temperature for $40 \mathrm{~min}$. Purified sequencing reactions were mixed with $20 \mu \mathrm{l}$ deionized formamide and heated at $95^{\circ} \mathrm{C}$ for $2 \mathrm{~min}$. Subsequently, the mixture was chilled on ice for 2-3 min. Separation of the DNA fragments was carried out in an ABI
PRISM 3100 Genetic Analyzer (Applied Biosystems). Time and voltage of sample injection were $22 \mathrm{~s}$ at $1 \mathrm{kV}$. Each run was performed at $50^{\circ} \mathrm{C}$, for $6500 \mathrm{~s}$, at $0 \cdot 1 \mathrm{~mA}$ and $12 \cdot 2 \mathrm{kV}$. Raw sequence data were transferred to AutoAssembler software (Applied Biosystems), where consensus sequences were determined. Consensus sequences were imported into BioNumerics 2.5 software, where a similarity matrix and phylogenetic trees were created, based on the neighbourjoining method (Saitou \& Nei, 1987) and maximumparsimony. Pearson's product-moment correlation coefficient and a regression curve were calculated between recA and $16 \mathrm{~S}$ rDNA data, based on 43 strains. The $16 \mathrm{~S}$ rDNA data were obtained from EMBL. Splits tree decomposition analysis was carried out using software available online (http://www. mlst.net; Huson, 1998) while Sawyer's test was calculated using the software package START obtained from http:// pubmlst.org/software/analysis/start/ (Jolley et al., 2001). EMBL accession numbers for the recA sequences are AJ580845-AJ580909.

In this study we sequenced a 739 bp fragment of recA of 62 Vibrionaceae strains, corresponding to approximately $70 \%$ of the coding region of this locus. We compared recA and 16S rDNA pairwise similarities between 43 strains using Pearson's product-moment correlation coefficient. The correlation of recA and 16S rDNA data was found to be relatively good, at $0 \cdot 58$ (see Supplementary Fig. A in IJSEM Online). The data fitted well in a polynomial regression of second degree $(r=0 \cdot 8)$. Overall, recA gene sequences were much more discriminatory than $16 \mathrm{~S}$ rDNA. For $16 \mathrm{~S}$ rDNA similarity values above $98 \%$, there was a wide range of recA similarities, from 83 to $99 \%$. The mean $( \pm \mathrm{SD}) \mathrm{G}+\mathrm{C}$ content of the recA gene sequences was $46 \cdot 9 \pm 2 \cdot 2 \mathrm{~mol} \%$. This value is in agreement with the $\mathrm{G}+\mathrm{C}$ content of the whole genome of vibrios (Thompson et al., 2003b, c), suggesting that this locus has not been affected by horizontal gene transfer. In addition, splits tree decomposition analysis and Sawyer's test did not indicate any evidence for recombination within the recA sequences in this study.

A neighbour-joining (NJ) tree with the estimated positions of the 71 representative Vibrionaceae strains based on $673 \mathrm{bp}$ is presented in Fig. 1. We also built a maximumparsimony tree that confirmed the grouping obtained by NJ. Vibrio species appear to be polyphyletic. Photobacterium species had at most $84 \%$ recA sequence similarity towards Vibrio species, but are apparently nested within vibrios. Photobacterium species did not form a homogeneous group, having recA similarity values ranging from 82 to $96 \%$. Baumann et al. (1983) suggested that Photobacterium and Vibrio are two distinct phylogenetic groups. The recA sequence similarities of Vibrio species were between 74 and $99 \cdot 6 \%$. Several Vibrio species formed deep branches e.g. V.gallicus, V. pacinii, Vibrio cincinnatiensis, Vibrio rumoiensis and Vibrio aestuarianus.

Vibrio diazotrophicus LMG $7893^{\mathrm{T}}$ and LMG 11217 were found in two different AFLP clusters, A57 and A34, respectively (Thompson et al., 2001a), and were later 


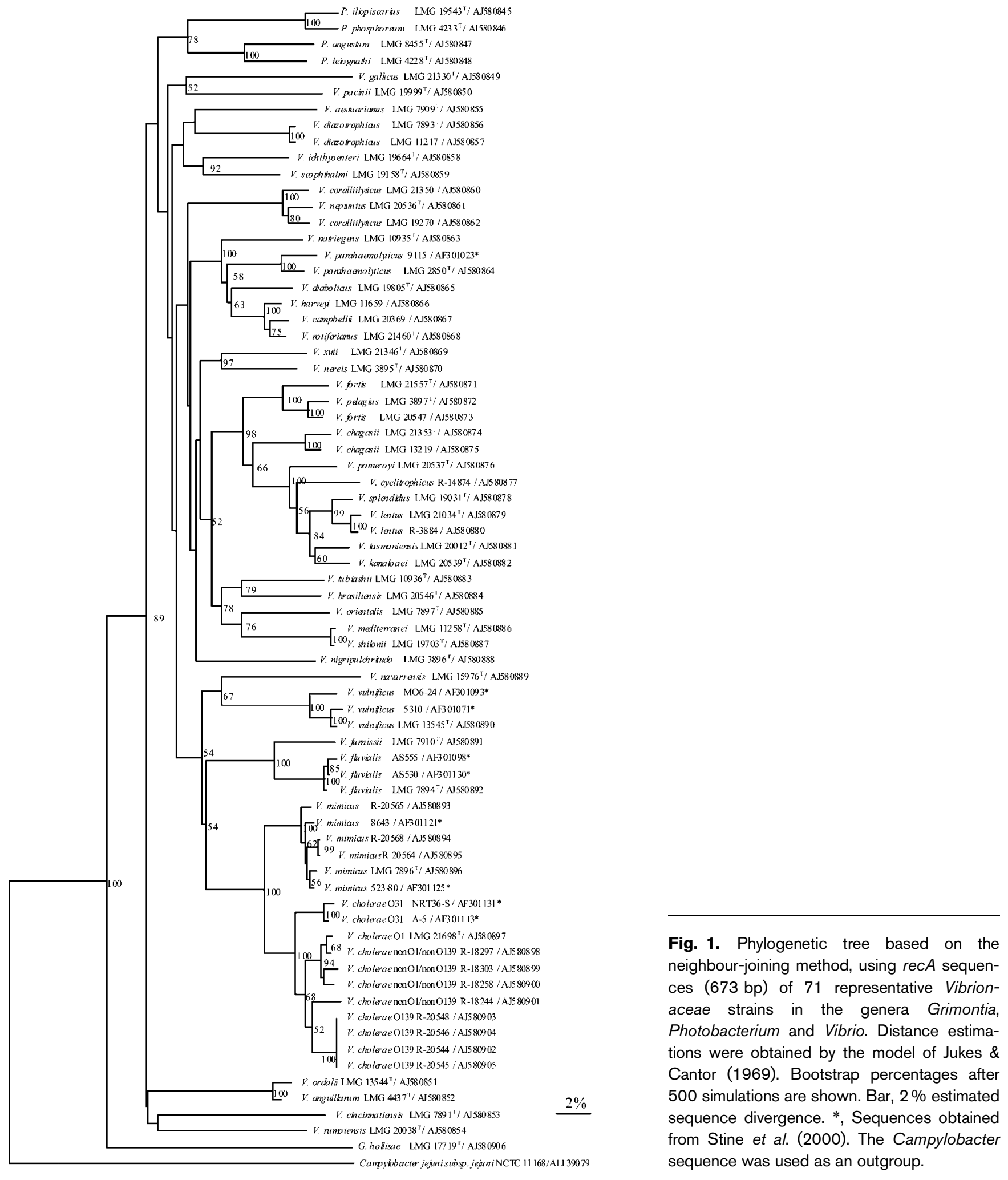

Fig. 1. Phylogenetic tree based on the neighbour-joining method, using $\operatorname{rec} A$ sequences (673 bp) of 71 representative Vibrionaceae strains in the genera Grimontia, Photobacterium and Vibrio. Distance estimations were obtained by the model of Jukes \& Cantor (1969). Bootstrap percentages after simulations are shown. Bar, 2\% estimated sequence was used as an outgroup.

confirmed by DNA-DNA hybridization to belong to the same species (unpublished data). Vibrio ichthyoenteri and Vibrio scophthalmi shared only $90 \%$ recA sequence similarity, but $99 \%$ similarity for the $16 \mathrm{~S}$ rDNA (Thompson et al., 2002).
V. coralliilyticus LMG 21350 and LMG 19270 shared 96.8\% $r e c A$ sequence similarity. These strains appeared within the former AFLP clusters A1 and A3, respectively (Thompson et al., 2001a). V. coralliilyticus and V. neptunius were phylogenetic neighbours, sharing $96 \%$ recA similarity. According 
to Ben-Haim et al. (2003), V. neptunius, V. tubiashii, V. nereis and Vibrio shilonii were the species most closely related to $V$. coralliilyticus, having 97 to $98 \% 16 \mathrm{~S}$ rDNA sequence similarity.

$V$. harveyi-related species, i.e. V. campbellii, Vibrio natriegens, $V$. parahaemolyticus and $V$. rotiferianus, had recA sequence similarities between 89 and $98 \%$. V. parahaemolyticus strains LMG $2850^{\mathrm{T}}$ and 9115 had $96 \%$ recA sequence similarity. Their closest neighbour was $V$. harveyi $(92 \%$ similarity). V. campbellii, V. harveyi and $V$. rotiferianus had about $97 \%$ recA sequence similarity. These species are highly related on the basis of $16 \mathrm{~S}$ rDNA sequences ( $>98 \%$ ), DNA-DNA hybridization $(>65 \%)$, Biolog and FAME (Gomez-Gil et al., 2003a).

$V$. nereis and $V$. xuii had $99 \% 16 \mathrm{~S}$ rDNA sequence similarity, but only $90 \%$ recA gene sequence similarity. Vibrio fortis and Vibrio pelagius were closely related by $16 \mathrm{~S} \mathrm{rDNA}(98 \cdot 8 \%)$ and DNA-DNA hybridization (65\%) (Thompson et al., 2003e), but the recA sequence similarity between these two species was only $94 \cdot 5 \%$. V. fortis LMG 20547 was closer to $V$. pelagius ( $98 \%$ recA sequence similarity) than to $V$. fortis LMG $21557^{\mathrm{T}}$, suggesting that strain LMG 20547 belongs to the species V. pelagius. LMG 20547 and the type strain of $V$. pelagius had $66 \%$ similarity by DNA-DNA hybridization (Thompson et al., 2003e).

V. chagasii LMG $21353^{\mathrm{T}}$ and LMG 13219 had $97 \%$ recA sequence similarity. These strains were found in the former FAFLP clusters A52 and A53, respectively (Thompson et al., 2001a). The closest neighbours of $V$. chagasii strains were $V$. fortis and $V$. pomeroyi, having at most $91 \%$ recA sequence similarity. V. pomeroyi, V. splendidus and Vibrio cyclitrophicus shared only $92 \%$ recA sequence similarity. $V$. splendidus had 93.7 and $95 \%$ recA sequence similarity towards $V$. kanaloae and $V$. tasmaniensis, respectively. $V$. tasmaniensis, $V$. pomeroyi and $V$. kanaloae shared at most $95.7 \%$ recA sequence similarity. Vibrio lentus LMG $21034^{\mathrm{T}}$ and R-3884 had $99 \%$ recA sequence similarity, but only $97 \%$ towards V. splendidus. V. lentus had 94 and $92 \%$ similarity towards $V$. tasmaniensis and $V$. cyclitrophicus, respectively. The $V$. splendidus-related group is very homogeneous on the basis of $16 \mathrm{~S}$ rDNA sequences $(>98.7 \%$ similarity), DNA-DNA hybridization ( $>50 \%$ ) and phenotype (Macian et al., 2001; Thompson et al., 2003c, d), suggesting that recA sequences are indeed valuable for the discrimination of these species.

The novel species $V$. neptunius, $V$. brasiliensis and $V$. xuii were closely related to $V$. tubiashii (98-99\% 16S rDNA gene sequence similarity) (Thompson et al., 2003b), but recA sequence similarity among these species was below $90 \%$. $V$. mediterranei and $V$. shilonii were almost identical by both $r e c A$ and $16 \mathrm{~S}$ rDNA. These results corroborate the proposal of Thompson et al. (2001b) that V. shilonii should be considered a later synonym of $V$. mediterranei.

V. vulnificus LMG $13545^{\mathrm{T}}$, MO6-24S and 5310 had recA sequence similarity between 96 and $99 \%$. Vibrio fluvialis LMG $7894^{\mathrm{T}}$, AS555 and AS530 shared more than $99 \%$ sequence similarity, whereas $V$. fluvialis and $V$. furnissii had at most $93 \%$ similarity. Strains AS555 and AS530 were identified by Stine et al. (2000) as V. parahaemolyticus, but our results indicate that they may belong to $V$. fluvialis.

Vibrio mimicus and V. cholerae, the two bona fide members of the genus Vibrio, were separated in two different groups. V. mimicus LMG $7896^{\mathrm{T}}, 523-80,8643$, R-20564, R-20565 and R-20568 shared at least $98 \%$ recA sequence similarity, while $V$. cholerae LMG $21698^{\mathrm{T}}$, A-5, NRT36-S, R-18244, R18258, R-18297, R-18303, R-20544, R-20545, R-20546 and $\mathrm{R}-20548$ had at least $94 \% \mathrm{rec} A$ sequence similarity. In our AFLP analysis, these R- strains were highly related and had $74-98 \%$ pattern similarity (Thompson et al., 2003f). $V$. cholerae strains included in this study represent well the currently known genomic diversity within this species (Thompson et al., 2003f), suggesting that recA is a valuable marker for the identification of $V$. cholerae strains. The rec $A$ similarity values between $V$. cholerae and $V$. mimicus were at most $94 \%$. Strains NRT36-S and A-5 clustered in between $V$. cholerae and $V$. mimicus. These strains appear to be at the outskirts of the species $V$. cholerae. Strains of different serogroups had very similar (99\%) recA sequences. $V$. cholerae LMG $21698^{\mathrm{T}}$ and R-18297 clustered together, having $99 \%$ recA similarity. All $V$. cholerae O139 strains had $100 \%$ similarity. Farfan et al. (2002) have highlighted that $V$. cholerae strains of different serogroups may have identical sequences. It has been argued that serogroup O139 strains have evolved from O1 strains (Faruque et al., 1998).

Vibrio ordalii and $V$. anguillarum showed a close relationship, having $98 \% \mathrm{rec} A$ sequence similarity. $V$. diazotrophicus LMG $7893^{\mathrm{T}}$ and LMG 11217 had more than $99 \%$ sequence similarity, and their closest neighbour was $V$. campbellii (86.9\% similarity). Grimontia hollisae was distantly related to Vibrio $(66 \cdot 3 \%$ sequence similarity) and Photobacterium $(70 \cdot 5 \%$ sequence similarity).

Until now, the backbone of bacterial systematics has been derived from the 16S rDNA sequence-based phylogeny (Ludwig \& Klenk, 2001). 16S rDNA is indeed the most useful chronometer to allocate strains to different branches of the family Vibrionaceae (Thompson et al., 2002). However, several vibrios have nearly identical $16 \mathrm{~S}$ rDNA sequences and this makes it difficult to use $16 \mathrm{~S}$ rDNA sequences to discriminate closely related species. Furthermore, phenotypic features are very similar among vibrios and so AFLP or DNA-DNA hybridization remain the techniques of choice for species identification. The grouping of the Vibrionaceae obtained on the basis of recA gene sequences reflects well the grouping based on $16 \mathrm{~S}$ rDNA gene sequences (Thompson et al., 2002). This study highlights the usefulness of $r e c A$ gene sequences as alternative phylogenetic markers for vibrios. Our data suggest that strains of the same species have at least $94 \%$ recA sequence similarity, but additional strains from each recognized species of the Vibrionaceae should be examined in future 
studies in order to confirm this threshold. We also intend to search for other alternative chronometers (Zeigler, 2003) which, in combination with recA, will provide a rapid and reliable means of identifying vibrios.

\section{Acknowledgements}

The authors thank Professor A. C. Vicente (Oswaldo Cruz Institute, Brazil) for providing $V$. cholerae and $V$. mimicus isolates. F.L.T. acknowledges a PhD scholarship (no. 2008361/98-6) from Conselho Nacional de Desenvolvimento Científico e Tecnológico (CNPq), Brazil. J.S. acknowledges grants from of the Fund for Scientific Research (FWO), Belgium.

\section{References}

Austin, B. \& Austin, D. A. (1999). Bacterial Fish Pathogens: Disease of Farmed and Wild Fish, 3rd edn. Berlin: Springer.

Baumann, P., Baumann, L., Woolkalis, M. J. \& Bang, S. S. (1983). Evolutionary relationships in Vibrio and Photobacterium: a basis for a natural classification. Annu Rev Microbiol 37, 369-398.

Ben-Haim, Y., Thompson, F. L., Thompson, C. C., Cnockaert, M. C., Hoste, B., Swings, J. \& Rosenberg, E. (2003). Vibrio coralliilyticus sp. nov., a temperature-dependent pathogen of the coral Pocillopora damicornis. Int J Syst Evol Microbiol 53, 309-315.

Byun, R., Elbourne, L. D., Lan, R. \& Reeves, P. R. (1999). Evolutionary relationships of pathogenic clones of Vibrio cholerae by sequence analysis of four housekeeping genes. Infect Immun 67, $1116-1124$.

Cox, M. M. (2003). The bacterial RecA protein as a motor protein. Annu Rev Microbiol 57, 551-577.

Eisen, J. A. (1995). The RecA protein as a model molecule for molecular systematics studies of bacteria: comparisons of RecA and $16 \mathrm{~S}$ rDNA trees for the same species. J Mol Evol 41, 1105-1123.

Farmer, J. J. \& Hickman-Brenner, F. W. (1992). The genera Vibrio and Photobacterium. In The Prokaryotes. A Handbook on the Biology of Bacteria: Ecophysiology, Isolation, Identification, and Applications. 2nd edn. pp. 2952-3011. Edited by A. Balows, H. G. Trüper, M. Dworkin, W. Harder \& K. H. Schleifer. Berlin: Springer.

Gomez-Gil, B., Roque, A., Turnbull, J. F. \& Tron-Mayen, L. (1998). Species of Vibrio isolated from hepatopancreas, haemolymph and digestive tract of a population of healthy juvenile Penaeus vannamei. Aquaculture 163, 1-9.

Gomez-Gil, B., Thompson, F. L., Thompson, C. C. \& Swings, J. (2003a). Vibrio rotiferianus sp. nov., isolated from cultures of the rotifer Brachionus plicatilis. Int J Syst Evol Microbiol 53, 239-245.

Gomez-Gil, B., Thompson, F. L., Thompson, C. C. \& Swings, J. (2003b). Vibrio pacinii sp. nov., from culture aquatic organisms. Int J Syst Evol Microbiol 53, 1569-1573.

Hayashi, K., Moriwaki, J., Sawabe, T., Thompson, F. L., Swings, J., Gudkovs, N., Christen, R. \& Ezura, Y. (2003). Vibrio superstes sp. nov., isolated from the gut of Australian abalones Haliotis laevigata and Haliotis rubra. Int J Syst Evol Microbiol 53, 1813-1817.

Heidelberg, J. F., Heidelberg, K. B. \& Colwell, R. R. (2002a). Bacteria of the gamma-subclass Proteobacteria associated with zooplankton in Chesapeake Bay. Appl Environ Microbiol 68, 5498-5507.

Heidelberg, J. F., Heidelberg, K. B. \& Colwell, R. R. (2002b). Seasonality of Chesapeake Bay bacterioplankton species. Appl Environ Microbiol 68, 5488-5497.

Huson, D. H. (1998). Splits tree: analysing and visualising evolutionary data. Bioinformatics 14, 68-73.
Jolley, K. A., Feil, E. J., Chan, M. S. \& Maiden, M. C. (2001). Sequence type analysis and recombinational tests (START). Bioinformatics 17, $1230-1231$.

Jukes, T. H. \& Cantor, C. R. (1969). Evolution of protein molecules. In Mammalian Protein Metabolism, pp. 21-132. Edited by H. H. Munro. London: Academic Press.

Le Roux, F., Gay, M., Lambert, C., Waechter, M., Poubalanne, S., Chollet, B., Nicolas, J. L. \& Berthe, F. (2002). Comparative analysis of Vibrio splendidus-related strains isolated during Crassostrea gigas mortality events. Aquat Liv Res 15, 251-258.

Lloyd, A. T. \& Sharp, P. M. (1993). Evolution of the $r e c A$ gene and the molecular phylogeny of bacteria. J Mol Evol 37, 399-407.

Ludwig, W. \& Klenk, H. P. (2001). Overview: a phylogenetic backbone and taxonomic framework for procaryotic systematics. In Bergey's Manual of Systematic Bacteriology: The Archeae and the Deeply Branching and Phototrophic Bacteria. 2nd edn. pp. 49-65. Berlin: Springer.

Macian, M. C., Ludwig, W., Aznar, R., Grimont, P. A. D., Schleifer, K. H., Garay, E. \& Pujalte, M. J. (2001). Vibrio lentus sp. nov., isolated from Mediterranean oysters. Int J Syst Evol Microbiol 51, 1449-1456.

Nishiguchi, M. K. (2000). Temperature affects species distribution in symbiotic populations of Vibrio spp. Appl Environ Microbiol 66, 3550-3555.

Pitcher, D. G., Saunders, N. A. \& Owen, R. J. (1989). Rapid extraction of bacterial genomic DNA with guanidium thiocyanate. Lett Appl Microbiol 8, 151-156.

Roca, A. I. \& Cox, M. M. (1990). The RecA protein: structure and function. Crit Rev Biochem Mol Biol 25, 415-456.

Rosenberg, E. \& Ben-Haim, Y. (2002). Microbial diseases of corals and global warming. Environ Microbiol 4, 318-326.

Saitou, N. \& Nei, M. (1987). The neighbor-joining method: a new method for reconstructing phylogenetic trees. Mol Biol Evol 4, 406-425.

Sawabe, T., Hayashi, K., Moriwaki, J., Thompson, F. L., Swings, J., Potin, P., Christen, R. \& Ezura, Y. (2004). Vibrio gallicus sp. nov., isolated from the gut of the French abalone Haliotis tuberculata. Int J Syst Evol Microbiol 54, 843-846.

Stine, O. C., Sozhamannan, S., Gou, Q., Zheng, S., Morris, J. G., Jr \& Johnson, J. A. (2000). Phylogeny of Vibrio cholerae based on recA sequence. Infect Immun 68, 7180-7185.

Suantika, G., Dhert, P., Rombaut, G., Vandenberghe, J., De Wolf, T. \& Sorgeloos, P. (2001). The use of ozone in a high density recirculation system for rotifers. Aquaculture 201, 35-49.

Thompson, F. L., Hoste, B., Vendemeulebroecke, K. \& Swings, J. (2001a). Genomic diversity amongst Vibrio isolates from different sources determined by fluorescent amplified fragment length polymorphism. Syst Appl Microbiol 24, 520-538.

Thompson, F. L., Hoste, B., Thompson, C. C., Huys, G. \& Swings, J. (2001b). The coral bleaching Vibrio shilonii Kushmaro et al. 2001 is a later synonym of Vibrio mediterranei Pujalte and Garay 1986. Syst Appl Microbiol 24, 516-519.

Thompson, F. L., Hoste, B., Thompson, C. C., Goris, J., Gomez-Gil, B., Huys, L., De Vos, P. \& Swings, J. (2002). Enterovibrio norvegicus gen. nov., sp. nov., isolated from the gut of turbot (Scophthalmus maximus) larvae: a new member of the family Vibrionaceae. Int J Syst Evol Microbiol 52, 2015-2022.

Thompson, F. L., Hoste, B., Vandemeulebroecke, K. \& Swings, J. (2003a). Reclassification of Vibrio hollisae as Grimontia hollisae gen. nov., comb. nov. Int J Syst Evol Microbiol 53, 1615-1617.

Thompson, F. L., Li, Y., Gomez-Gil, B. \& 8 other authors (2003b). Vibrio neptunius sp. nov., Vibrio brasiliensis sp. nov., and Vibrio xuii 
sp. nov., isolated from the marine aquaculture environment (bivalves, fish, rotifers and shrimps). Int J Syst Evol Microbiol 53, 245-252.

Thompson, F. L., Thompson, C. C., Li, Y., Gomez-Gil, B., Vandenberghe, J., Hoste, B. \& Swings, J. (2003c). Vibrio kanaloae sp. nov., Vibrio pomeroyi sp. nov., and Vibrio chagasii sp. nov., from sea water and marine animals. Int J Syst Evol Microbiol 53, 753-759.

Thompson, F. L., Thompson, C. C. \& Swings, J. (2003d). Vibrio tasmaniensis sp. nov., isolated from Atlantic salmon (Salmo salar L.). Syst Appl Microbiol 26, 65-69.

Thompson, F. L., Thompson, C. C., Hoste, B., Vandemeulebroecke, K., Gullian, M. \& Swings, J. (2003e). Vibrio fortis sp. nov., and Vibrio hepatarius sp. nov., isolated from aquatic animals and the marine environment. Int J Syst Evol Microbiol 53, 1495-1501.

Thompson, F. L., Thompson, C. C., Vicente, A. C. P., Theophilo, G. N. D., Hofer, E. \& Swings, J. (2003f). Genomic diversity of clinical and environmental Vibrio cholerae strains isolated in Brazil between 1991 and 2001 as revealed by FAFLP analysis. J Clin Microbiol 41, 1946-1950.

Urakawa, H., Yoshida, T., Nishimura, M. \& Ohwada, K. (2000). Characterization of depth-related population variation in microbial communities of a coastal marine sediment using 16S rDNA-based approaches and quinone profiling. Environ Microbiol 2, 542-554.

Wachsmuth, I. K., Blake, P. A. \& Olsvik, O. (1994). Vibrio cholerae and Cholera. Molecular to Global Perspectives: Washington, DC: American Society for Microbiology.

WHO (2001). Cholera, 2000. Wkly Epidemiol Rec 76, 233-240.

WHO (2002). Cholera, 2001. Wkly Epidemiol Rec 77, 257-268.

Zeigler, D. R. (2003). Gene sequences useful for predicting relatedness of whole genomes in bacteria. Int J Syst Evol Microbiol 53, 1893-1900. 